\title{
GLAGOLJICA I ĆIRILICA PLODOVI SU DVIJU ODVOJENIH BIZANTSKIH MISIJA MEĐU SLAVENIMA
}

\author{
Mile Bogović \\ Gospićko-senjska biskupija \\ Senjskih žrtava 36 \\ HR 53000 Gospić
}

\author{
UDK: 003 \\ 94(497.5)"11" \\ Izvorni znanstveni članak \\ Ur.: 2021-06-04
}

\begin{abstract}
Obično se govori i piše da su glagoljica i ćirilica u svojim početcima vezane uz Moravsku misiju čiji su glavni protagonisti bili Konstantin-Ćiril i njegov brat Metod. Autor ovog teksta smatra da je svako od tih dvaju pisama vezano uz jednu od dvije različite misije u različite prostore i u različito vrijeme. Glagoljica je nastala u početcima pokrštavanja Slavena u Hrvatskoj (Bizantskoj Dalmaciji) i krajevima oko Soluna (Makedoniji), a ćirilica je vezana uz djelovanje Svete braće Ćirila i Metoda u vrijeme Moravske misije (863. - 885.). Oba pisma djelo su iste bizantske misionarske škole, ali je glagoljica nastala ranije i to iz čisto misijskih potreba, a ćirilica je nastala u vrijeme jake državno-političke ekspanzije Bizanta među Slavenima u vrijeme "velikog bizantskog decenija" (870. - 880.).

U vrijeme velikog Raskola (1054.) Rim će tražiti od glagoljaša na području svoje jurisdikcije u Hrvatskoj da prihvate rimski ili latinski obred. U Makedoniji je glagoljica izgubila svaku podršku i svuda je uzmicala pred ćirilicom te je u 12. stoljeću sasvim nestala u bizantskom obredu. Budući da su oba pisma nastala za isti (slavenski) jezik, pod jezičnim vidom nastavljene su među njima veze, što se primijeti u glagoljičkim i ćiriličkim tekstovima.
\end{abstract}

Ključne riječi: glagoljica, ćirilica, obredi, misionarske škole, Raskol 1054., Bizantska Dalmacija, Makedonija

\section{Uvodno}

Cijeli svoj radni vijek predavao sam paralelno Povijest Crkve u Hrvata i Hrvatsku glagoljsku kulturu. Mnogo puta sam se suočio s nepremostivim teškoćama kada sam uzaludno pokušavao uskladiti ćirilometodsku teoriju o nastanku glagoljice s onim što nam nudi povijesna znanost. Već sama činjenica da ima mnogo teorija o postanku, razvoju i proširenju glagoljice i staroslavenskog bogoslužja, ukazuje da sve "kockice" još nigdje nisu sjele na svoje pravo mjesto, pa se i dalje pokušava njihovo novo preslagivanje. Ključni problem je u tome 
što se u najraširenijoj (ćirilometodskoj) teoriji nastoji vezati nastanak jednoga i drugoga, i pisma i bogoslužja, uz iste osobe i uz isto vrijeme. U ovom tekstu pokušat ću obrazložiti svoje mišljenje da je u prvoj ili ranoj misiji, u Makedoniju i Hrvatsku (Bizantsku Dalmaciju), pismo bila glagoljica, a u drugoj ili kasnijoj, onoj koja je 863. krenula predvođena Konstantinom Ćirilom i Metodom u Moravsku, pismo je bilo ćirilica. ${ }^{1} \mathrm{U}$ obrazlaganju, dakle, stavljam fokus na pismo, ali se uvijek ima u vidu i bogoslužje. Ima mnogo toga što ta dva pisma - glagoljicu i ćirilicu - doista veže: oba su nastala u bizantskom obredu i od misionara koji su poslani iz Bizanta, ali razlika je u tome što to nije bilo $u$ isto vrijeme, $u$ istim okolnostima i na istim prostorima. Činjenica je da je glagoljica u drugom tisućljeću živjela u rimskom obredu, a ćirilica u bizantskom pa ćemo u traženju korijena glagoljice krenuti od tih dvaju obreda - bizantskog i rimskog. Raskol u kršćanstvu 1054. na pravoslavlje i katolicizam odrazio se i na sudbinu obaju pisama - glagoljice i ćirilice.

Što se dogodilo i koji su po mome sudu tome uzroci, prikazat ću u nastavku. U svom istraživanju trudio sam se problematiku sagledati interdisciplinarno, povezujući vjersku i povijesnu stranu teme jer se samo tako može ispravno smjestiti i vrednovati neprijeporne rezultate filološke znanosti na ovom polju.

\section{Bizantski ili grčki i rimski ili latinski obred}

Najprije treba reći da su ta dva obreda živjela uglavnom u mirnom suživotu dok je bio dobar odnos između istočnog i zapadnog kršćanstva, a kada je došlo do loma između tih dviju strana, odrazilo se to i na odnose među tim obredima. Kako je već rečeno, oba pisma, glagoljica i ćirilica, nastala su u istom bizantskom obredu, ali se glagoljica nakon Raskola sačuvala gotovo isključivo samo u latinskom, a ćirilica u bizantskom obredu.

Obred je način kako se vrši služba Božja i službena molitva u kršćanskim crkvama: u euharistiji (misi), sakramentima i časoslovu. Važnu ulogu u obredima ima liturgijski jezik i pismo. Obredi su najvidljiviji znak i izričaj inkulturacije kršćanstva u razne kulture i civilizacije, što znači da zahvaća i običaje i umjetnički

${ }^{1}$ To sam obradio u svojoj knjizi: Glagoljica bitna odrednica hrvatskog identiteta, Zagreb, 2019, 30-37. Ovdje ujedno ispravljam i dopunjujem ono što o putu glagoljice u Hrvatsku rečeno u toj knjizi jer je očito da je kraj oko Soluna, s obzirom na naseljenost Slavena, bio u sličnoj situaciji kao i područje Bizantske Dalmacije pa su taj kraj i Bizantska Dalmacija mogli biti kristijanizirani u sklopu iste misije koja je došla u Dalmaciju. Prvotno sam mislio da su glagoljske knjige u Makedoniju došle nakon što su neki hrvatski monasi poslije 1054. morali napustiti Dalmaciju. Za neke knjige to i vrijedi, ali svakako su neke ondje postojale i prije. 
izraz. Uz rimski obred vezan je i svećenički celibat, a za istočne obrede celibat je obveza samo redovništva (monaštva). Ima i drugih neliturgijskih običaja koji su vezani uz pojedine obrede.

Prva je Crkva bila višeobredna i multikulturalna, a svaka je lokalna Crkva u obredima izrazila evanđelje i vjeru apostola na vlastiti način, prema geniju svoje kulture. Svetopisamske tekstove, dakako, ne smije nijedan obred mijenjati, ali u bogoslužju postoje razne molitve i pjesme, što se može prilagoditi vremenu i kulturi. U kršćanstvu je na Zapadu sačuvan samo rimski ili latinski obred iako ih je prije raskola 1054. bilo više. Istočno kršćanstvo sačuvalo je više obreda: bizantski, antiohijski, maronitski, armenski, kaldejski, koptski i etiopski. Na Istoku je bilo više razvijenih kultura i jezika, pa se to odrazilo i na stvaranje više obreda. Najrašireniji je na Istoku bizantski ili grčki obred. Ovdje ćemo govoriti samo o rimskom ili latinskom i bizantskom ili grčkom obredu jer je do Raskola glagoljica bila početno u bizantskom obredu, a nakon Raskola 1054. sačuvala se samo u rimskom. ${ }^{2}$

Bizantski ili grčki obred proširen je na sve pravoslavne Slavene. U pokrštavanju Slavena bizantski misionari su uvodili narodni jezik i posebno pismo koje odgovara slavenskim glasovima.

Rimski obred bio je na Zapadu najrašireniji kršćanski obred, ali je u prvom tisućljeću bilo i drugih obreda. Nakon Raskola 1054. uglavnom su svi nestali, a posebni obredi sačuvali su se u katedralama u Toledu (mozarapski ili španjolski) te u Milanu (ambrozijanski). Ne samo redovnici nego i svi svećenici obvezni su na beženstvo (celibat). Jezik je u rimskom obredu bio do Drugog vatikanskog koncila latinski, a pismo latinica. Jedino je u Hrvatskoj sačuvan staroslavenski jezik i pismo glagoljica. Tako je bilo u misi gotovo jedno tisućljeće, sve tamo od Raskola 1054. pa do izdanja staroslavenskog misala u latiničnoj transkripciji 1927. godine. ${ }^{3}$ Obrednik je već 1640 . objavljen na govornom hrvatskom jeziku i na latinici, a zadnji časoslov tiskan je glagoljicom 1791. Poslije toga molio se iz latiničnih izdanja.

${ }^{2}$ Ovaj sud ne mora imati apsolutnu vrijednost jer je moguće da se glagoljica širila s područja Bizantske Dalmacije na prostore hrvatske kneževine i kraljevine, gdje se mogla širiti samo u latinskom obredu, ali to još do sada nije istraženo pa se može samo nagađati što je i kako je bilo.

${ }^{3}$ Rimska Crkva je sve do 1248. godine podnosila glagoljicu i staroslavensko bogoslužje. Uporaba glagoljice bila je dopuštena samo nižem kleru. Tek tada je Crkva uočila da bi glagoljica i staroslavensko bogoslužje mogli biti pogodno sredstvo za sjedinjenje pravoslavnih Slavena s Katoličkom Crkvom, pomagala je glagoljicu i odgoj glagoljskog klera. Senjski biskup Filip dobio je 1248. pismom pape Inocenta IV. dopuštenje da i on može glagoljati svuda gdje taj običaj postoji. U cijeloj Katoličkoj Crkvi jedino je - nakon 1248. - pjevana misa mogla biti samo na staroslavenskom. Vidi opširnije u: M. BOGOVIĆ, 2019, 76-84. 
Nakon crkvenog sabora u Lionu 1215. nisu na Zapadu više bili zabranjeni istočni obredi i jezici. Ako je neka crkvena zajednica prihvatila zajedništvo s Katoličkom Crkvom, sačuvala je i obred i jezik. ${ }^{4}$ U slučajevima da je neka zajednica iz pravoslavlja ili istočnih crkava prihvatila zajedništvo s papom i Katoličkom Crkvom, sačuvala je i dalje prijašnji obred.

\section{Različite metode misijskog djelovanja na Istoku i na Zapadu}

Za lakše shvaćanje uloge obreda u prihvaćanju različitih jezika i pisma potrebno je reći nešto o razlikama misijskih metoda ili škola na Zapadu i na Istoku.

Poznata je praksa bizantskih misionara da su za velike narode uvodili narodni jezik u bogoslužje. Bizantskom je misionaru bilo svakako poznato da se od Jadrana do Urala naselio narod Slavena i da već na početku rada treba računati s time. A početak misionarskog rada među Slavenima nije bio u drugoj polovici devetog stoljeća, tj. u doba Ćirila i Metoda, nego mnogo prije. Slavena je bilo već u 7. stoljeću u nekim krajevima gdje su se sačuvale strukture Rimskog Carstva i Crkve. Tu je svako odlaganje bilo nedopustivo. To su uglavnom krajevi gdje su Slaveni došli do mora, a negdje prešli i na otoke, kao na istočnoj obali Jadrana. Kako je već rečeno, na Istoku je bilo više razvijenih kultura i jezika pa bizantskim misionarima nije bilo teško prihvatiti da ti jezici uđu u liturgiju. Takvi jezici imali su i svoju pismenost, svoja slova. Ta praksa vrijedila je i za nove veće narode iako kod njih jezik nije razvijen i nemaju svoja slova. Za njih se stvaraju i formuliraju elementi gramatike, rječnici i nova slova. Nije teško bilo bizantskim misionarima shvatiti da treba stvoriti neka nova slova adekvatna postojećem jeziku, jer svi jezici nemaju iste glasove (foneme) pa onda ne mogu imati ni ista slova (grafeme). ${ }^{5}$

U bizantskoj misionarskoj školi ${ }^{6}$ osjetili su već po dolasku Slavena u 7. stoljeću na područje Bizantske Dalmacije i okolice Soluna da tamo treba

${ }^{4}$ Bilo je to nakon što su križari 1204. uspostavili Latinsko carstvo na Bosporu. U tom kontekstu treba gledati i pismo pape Inocenta IV. 1248. senjskom biskupu Filipu da može glagoljati svuda gdje postoji taj običaj (M. BOGOVIĆ, 2019, 59-67).

${ }^{5}$ I zapadni misionar bio je prvi učitelj novih naroda koji su došli na područje Carstva. Znakovito je da se nisu dosjetili da bi pri tom za one glasove koje nema latinica stvorili nove znakove (slova) nego sve do danas imamo nevjerojatnu zbrku da se za jedan glas stavlja više latiničnih slova (sch-̌̌s, tsch-č, i sl). Bizantska misionarska škola imala je bogatije iskustvo pa takve kombinacije nisu bile potrebne.

${ }^{6}$ Ovdje riječ "škola" ne znači neku trajnu ustanovu nego trajnu praksu bizantske Crkve. Nije misionar u misijama bio bez smjernica iz crkvenog središta. Da je formulirana jedna praksa bizantske Crkve, vidi se po načinu djelovanja bizantskih misionara u različitim krajevima. 


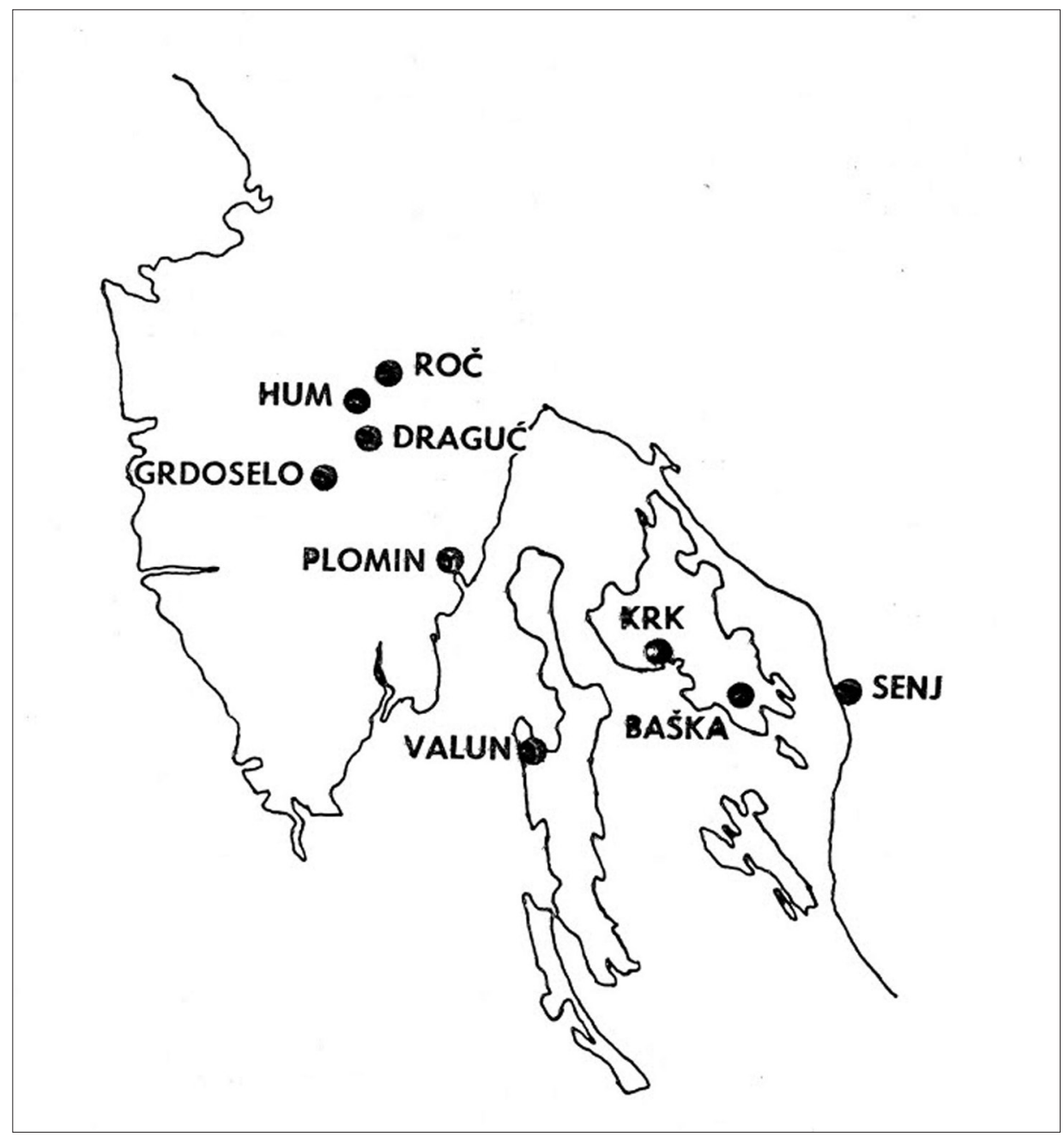

Sl. 1. Glagoljski natpisi na području Riječke metropolije od XI. do XIII. st. (izvor: B. FUČIĆ, 1982, 2)

poslati misionare. Možemo reći da je na spomenutim prostorima ubrzo nakon naseljavanja Slavena otvoren prostor za misijsku djelatnost. Kada je neki narod prihvatio kršćanstvo, time je odmah preuzeo zadatak da ga proširi i na susjedni narod. Tim više je Crkva na spomenutim prostorima, gdje kršćanstvo nije nikada nestalo, osjetila dužnost kristijanizirati nekršćane Slavene u svom susjedstvu. Nije ta kristijanizacija prepuštana željama pojedinih misionara. 


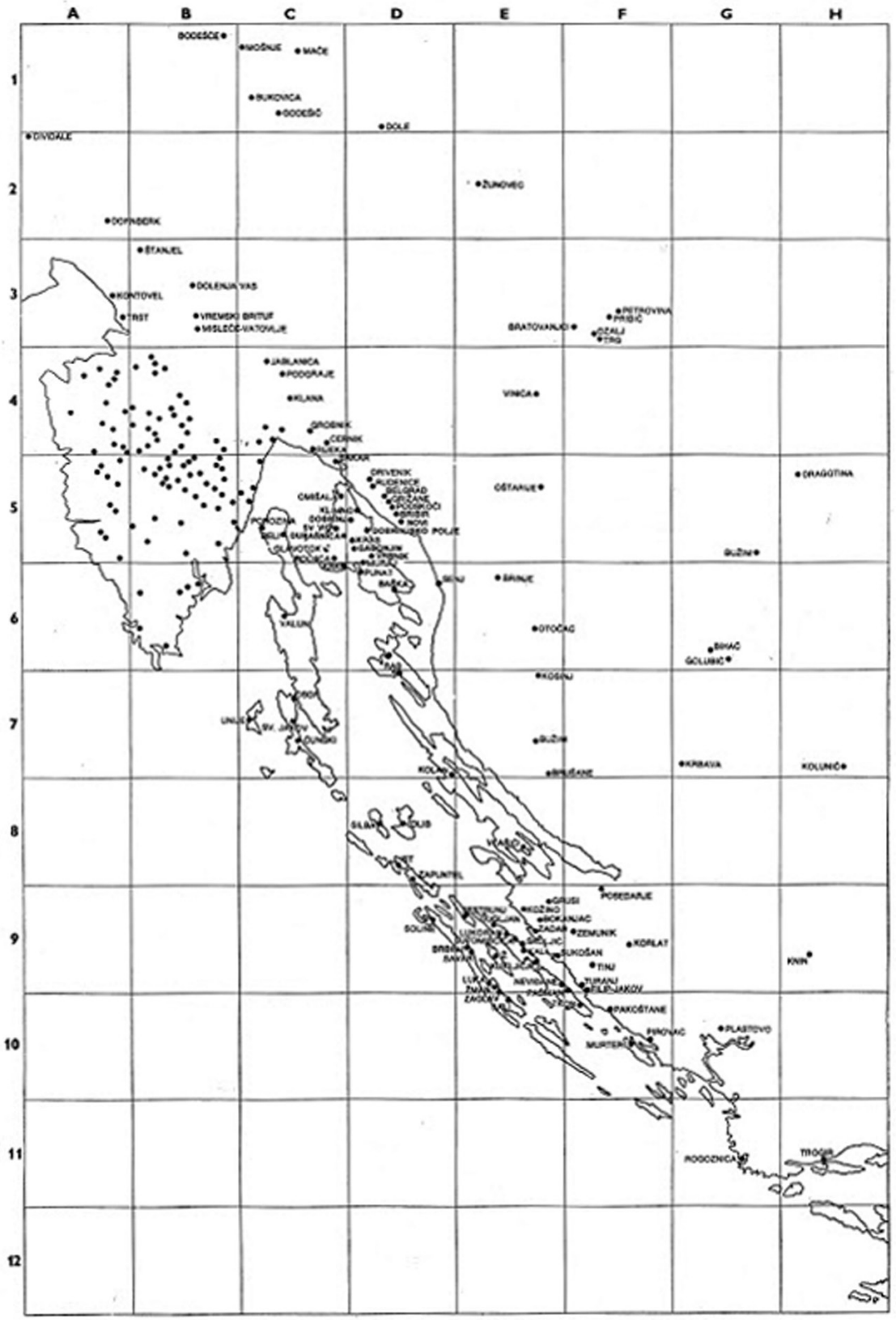

Sl. 2. Glagoljski natpisi u Hrvatskoj, Sloveniji, Bosni i Hercegovini (izvor: B. FUČIĆ, 1982, 4) 


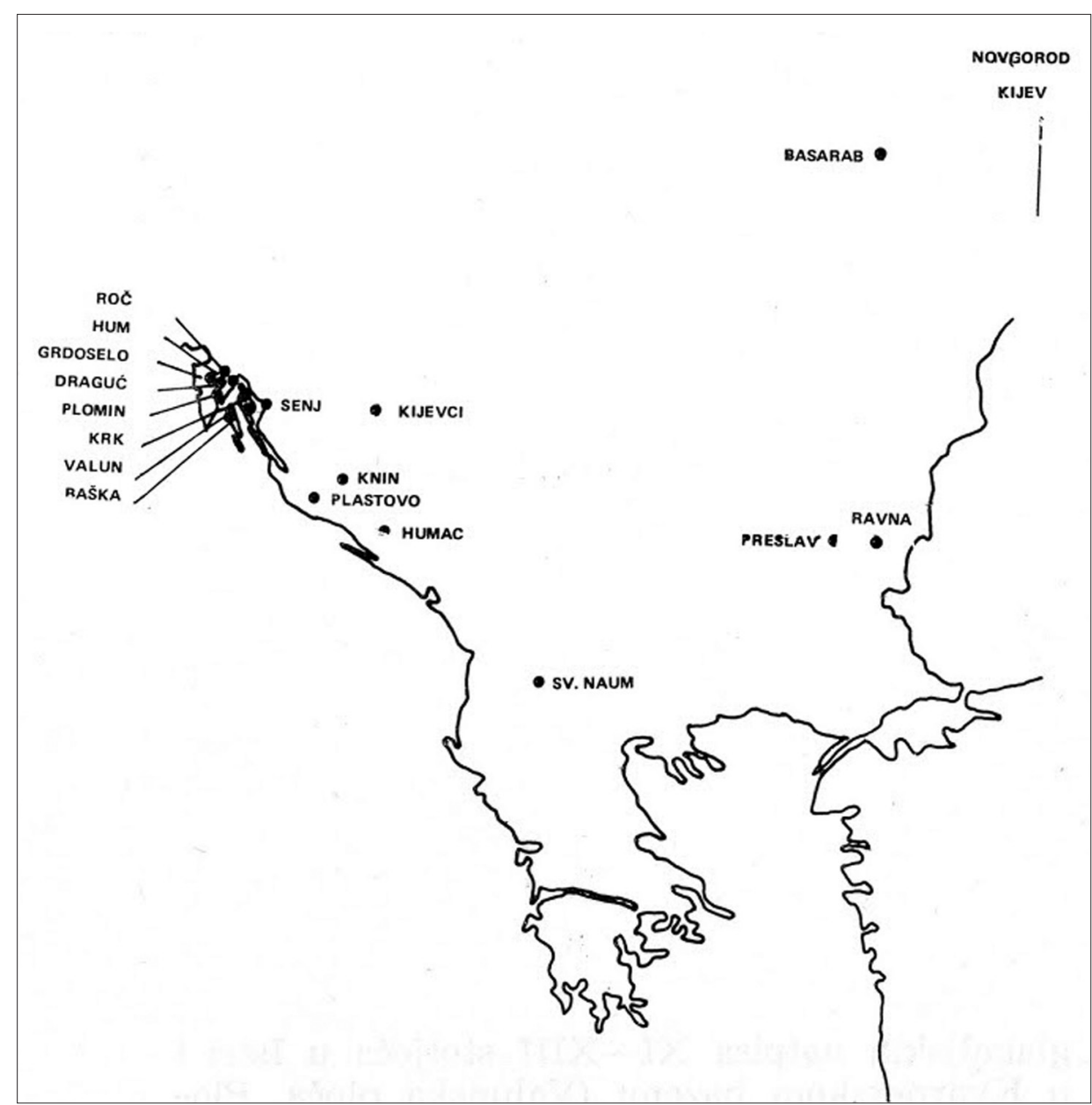

Sl. 3. Topografija glagoljskih natpisa u periodu od X. do XIII. stoljeća (izvor: B. FUČ́IĆ, 1982, 2) ${ }^{7}$

Svi su oni imali direktive kako to raditi. Sasvim je razumljivo da su se među pokrštenim Slavenima našlo svećenika koji su otišli među Slavene izvan toga prostora. Ti početci kristijanizacije, dakle, bili su daleko prije Ćirila i Metoda. Uz to, za Hrvatsku nemamo nikakvih podataka da su ovdje uopće boravili Ćiril i Metod, a jednako tako ni da su ovamo došli protjerani Metodovi učenici. No,

${ }^{7}$ Nakon objavljivanja ove knjige otkriveno je i objavljeno još glagoljskih natpisa, ali to ne mijenja ovdje iznesenu prosudbu. 
usprkos toj činjenici, upravo u Hrvatskoj nalaze se svi kameni (neprenosivi!) glagoljski natpisi. Oni su najsigurniji svjedoci da je ovdje glagoljica živjela odavna. Kada stanemo pred Fučićevu kartu neprenosivih glagoljskih natpisa, ne možemo se ne čuditi kako je nekome palo na pamet tražiti put glagoljice iz Moravske u Hrvatsku, kad u Moravskoj nemamo nijednog glagoljskog natpisa. ${ }^{8}$ (Vidi Sl. 1-2.)

Ako postoji neki natpis izvan Hrvatske, to su grafiti (ugrebotine), a ne slova uklesana u kamen. Grafiti mogu značiti da je tuda glagoljica prolazila (zidari, slikari, prolaznici), a ne mora značiti da je ondje i živjela. Na priloženoj karti (Sl. 3) možemo vidjeti gdje se nalaze glagoljski natpisi u hrvatskim krajevima i izvan njih.

Zapad je imao drukčiju misionarsku praksu od Bizanta. Na Zapadu je bio samo jedan razvijeni jezik (latinski) i jedno općeprihvaćeno pismo (latinica). ${ }^{9}$

Početna misija među Slavenima bila je glagoljska, a u Moravskoj ćirilička - jedna i druga bile su u bizantskom obredu

Područje koje su naselili Hrvati nalazilo se zapadno od rijeke Drine, u zapadnom Iliriku, gdje je crkvenu jurisdikciju imao zapadni patrijarh, odnosno rimski biskup. Po tome bi svi Hrvati trebali primiti rimski obred. Tako je u većem dijelu i bilo, pogotovo nakon dolaska franačke vlasti i razvoja hrvatske kneževine i kraljevine.

Otoke i priobalje također su naselili Hrvati. Taj prostor zvao se u ranom srednjem vijeku Bizantska Dalmacija jer je ondje bila dugo bizantska vlast. Za Dalmaciju nam je poznato da se u vrijeme Velike seobe naroda staro stanovništvo povuklo u gradske zidine, a na napuštene prostore dolaze Slaveni (Hrvati) i razvija se malo po malo jako slavensko (hrvatsko) selo i seoska općina, neovisna od grada. Slično je bilo i u slavenskom dijelu Makedonije. To su oni prostori na kojima su bizantske institucije preživjele doseljenje novih stanovnika; ondje su nezavisne kolone na posjedima zamijenili nezavisni seljaci, mahom slavenskog porijekla ${ }^{10}$. Te krajeve od Carigrada do Istre povezivao je u ranom srednjem vijeku hodočasnički put, kako vidimo u

${ }^{8}$ Pričao je Branko Fučić da su ga pozvali u Prag kako bi vidio kamen na kojemu je bio neki znak. Ponadali su se da je glagoljsko slovo. Kaže da ih je morao razočarati jer taj znak nije imao sličnosti ni s jednim glagoljskim slovom (Fučić je poznavao dobro svako slovo i svaku njegovu nijansu).

${ }^{9}$ Bilo je i na Zapadu nekoliko sličnih inicijativa, ali su nakon raskola 1054. dokinute.

${ }^{10}$ G. OSTROGORSKI, 1970, 45-58. 
atlasu crkvene povijesti. ${ }^{11}$ Po vanjskom rubu sjevernojadranskih otoka išao je bizantski plovni put sve do Istre. Duž putova bile su utvrde koje su istodobno bile i izvidnice i zbjegovi za prihvat i opskrbu ugroženih brodova. "Izgradnju svih ovih utvrda možemo prema tehnici gradnje smjestiti u 6. i 7. stoljeće, premda na nekim lokalitetima ima ostataka i starije gradnje". ${ }^{12}$

$\mathrm{Na}$ tom području, uz to što su sačuvane stare ustanove Carstva, mogle su preživjeti i neke ustanove i pravne forme koje je novo stanovništvo donijelo sa sobom jer su gradovi bili preslabi da bi im se nametnuli svojim pravnim sustavom. Hrvati (Slaveni) imali su svoje običaje i neki svoj životni red koji su donijeli sa sobom. Zacijelo nisu došli kao gomila bez ikakva reda. ${ }^{13}$ To vrijedi i za krajeve oko Soluna (Makedonija), a dakako i za prostor Bizantske Dalmacije, posebno za sjevernojadranske otoke i Istru, gdje su sačuvani najjasniji tragovi njihovih prometnica. U južnijim dijelovima Dalmacije nije bilo toliko prostora za razvoj hrvatskog sela i samostalnih seoskih općina kao na sjevernojadranskim otocima i u Istri. ${ }^{14}$ To se odrazilo i na slabiju prisutnost glagoljice.

\section{Potrebno je novo preslagivanje "kockica"}

Iako je danas u znanosti uglavnom prihvaćeno da je glagoljica došla iz Bizanta, još se uvijek mnogi kolebaju je li se ona širila od kopna prema obali i otocima, ili obratno. Te nejasnoće postoje zato što se cjelokupna misijska djelatnost pokrštavanja Slavena i njihova pismenost vežu uz Ćirila i Metoda. Dok god se tako bude gledalo, rađat će se nove teorije jer sada prevladavajuća ćirilometodska teorija ima previše nejasnoća i praznina.

Još u drugoj polovici 18. stoljeća najbolji poznavatelji glagoljice i jezika staroslavenskih liturgijskih knjiga, zadarski nadbiskup Mate Karaman i njegov učenik Matej Sović, jasno govore da je glagoljica starija od Moravske misije Ćirila i Metoda. U svom djelu Del clero illirico (O glagoljskom kleru), Karaman je osmo poglavlje naslovio: "Glagoljica je postojala prije Ćirila i Metoda". ${ }^{15}$ Nakon toga javlja se sveslavenski pokret koji naglo prerasta u ideologiju.

${ }^{11}$ Atlas zur Kirchengeschichte, 1987, karta 18.

${ }^{12}$ A. BADURINA, 1972, 7-9.

${ }^{13} \mathrm{Ti}$ će običaji poslije doći do izraza i u pisanom obliku kao npr. Vinodolskom zakonu, a vjerojatno i u onom koji mu je prethodio na cijelom frankopanskom području, na Krku i u Istri gdje je postojalo jako i organizirano selo.

${ }^{14}$ N. BUDAK - T. RAUKAR, 2006, 122-123.

${ }^{15}$ M. BOGOVIĆ, 2019, 174. 
Ćirilometodska teorija o postanku glagoljice nastala je u okvirima ćirilometodske ideje koja je Slavenima nudila rješenja za vjerska, politička i kulturna pitanja. Nastala je u vrijeme rađanja pokreta sveslavenskog zajedništva i solidarnosti. Sveslavenska ideologija je stvorila kontekst u koji je trebalo smjestiti i nastanak najstarijeg slavenskog pisma - glagoljice. ${ }^{16}$ Takva tumačenja dobivala su često i svoju političku potporu. Iskakanje iz tih ideoloških kola bilo je katkada politički opasno, čak i kažnjivo. Teorija se nametnula kao racionalan okvir i kodeks unutar kojega su postavljene i norme za znanstveno istraživanje te tematike, a sve što je izvan toga smatra se diletantizmom. Nema, dakako, sumnje da su i u tim okvirima i po tom kodeksu nastajala vrhunska znanstvena djela koja će i u budućnosti sačuvati svoju vrijednost. No, zabluda je u vremenu i prostoru nastanka glagoljice i ćirilice. Prema ćirilometodskoj teoriji, kad je bizantski car Mihajlo III. dobio poziv moravskog kneza Rastislava da mu pošalje misionare, car je rekao učenom Konstantinu (Ćirilu) da stvori odgovarajuća slova za moravski (slavenski) jezik. Konstantin se, kako kaže predaja, pomolio Bogu i stvorio novo pismo koje će se poslije nazvati glagoljica. S tim glagoljskim pismom i liturgijskim knjigama po bizantskom obredu krenuo je 863. Konstantin s bratom Metodom i s učenicima u Moravsku. U Moravskoj su braća prihvatila rimski obred. ${ }^{17}$ Konstantinovo pismo odobrio je papa Hadrijan II. 869. godine. Nakon Ćirilove smrti Metod je nastavio misiju u Moravskoj i okolici, ali nakon njegove smrti 885. učenici su bili protjerani i time je u Moravskoj završena misija započeta 863 . godine. Prognani učenici nastavili su je, kako se tvrdi u toj teoriji, u Bugarskoj i Hrvatskoj. No, u Bugarskoj

${ }^{16}$ G. DARTEL, 1984, 58-59; L. TANDARIĆ, 1986, 373.

${ }^{17} \mathrm{U}$ novije vrijeme pitanjem početaka slavenske liturgije bavi se liturgičar Kristijan Kuhar. Njegovim ulaskom na ovo područje ono je obogaćeno jednom novom dimenzijom koja je nužno za rad na ovom polju. U najnovijem radu bavi se najstarijim tekstovima slavenske liturgije rimskog obreda (K. KUHAR, 2018, 171-197). I pored izvanrednih analiza, ostaje čvrsto uz ćirilometodsku teoriju pa se i kod njega osjeća da se "kockice" ne drže dobro na mozaiku. Nije dokazao zašto izabrane tekstove (Kijevske listiće, Bečke listiće, Splitski fragment misala i Vatikanski misal Illirico 4) veže uz Moravsku misiju, niti zašto bi Ćiril i Metod trebali u Moravskoj mijenjati obred. On to tumači time što je ondje već bila uvedena liturgija u rimskom obredu i jer su Sveta braća došla na područje papinske jurisdikcije. Tu se javljaju mnogi problemi jer je na području papinske jurisdikcije u ono vrijeme bilo u mirnom suživotu više obreda, pa čak je i u Rimu bilo crkava i zajednica bizantskog obreda. Druga slabost te argumentacije je u tome što su Ćiril i Metod valjda znali kamo idu pa bi se od njih očekivalo da prije polaska pripreme liturgiju u rimskom obredu. Njegovi dokazi da su prijevodi u spomenutim knjigama pod utjecajem sakramentara s akvilejskog područja više idu u prilog tvrdnji da su navedene liturgijske knjige vezane uz hrvatski prostor, a ne uz Moravsku misiju. 
je nedugo zatim na Preslavskoj sinodi 893. uvedena ćirilica kao službeno bugarsko pismo. U zapadnim dijelovima Bugarskog carstva (Makedoniji) glagoljica se sačuvala jedno vrijeme, a u Hrvatskoj je ona nastavila živjeti do kraja 19. stoljeća. Uglavnom se svi slažu da je glagoljica starija od ćirilice, a i jezikoslovci su utvrdili da je ćirilica preuzimala neke elemente iz starije glagoljice.

Moje je mišljenje također da je glagoljica starija i od Ćirila i od Moravske misije. ${ }^{18}$ Ćiril je autor ćirilice, što sugerira i ime pisma; i Sveta braća su s ćirilicom, a ne s glagoljicom, krenula u Moravsku. Iz Moravske su njihovi prognani učenici donijeli u Bugarsku ćirilicu i zato se moglo dogoditi da je to pismo 893. (samo osam godina nakon protjerivanja Metodovih učenika iz Moravske!) proglašeno službenim pismom u bugarskoj državi. ${ }^{19}$ Dakako, treba voditi računa i o činjenici da je car Simeon prethodno bio monah i da je odgojen u grčkoj kulturi. On je odgojen u onoj ideologiji koja je tada bila dominantna na bizantskom dvoru i u početku Moravske misije. U velikom bizantsko deceniju (860. - 870.) Bizant je već definirao državnu i crkvenu strategiju prema Slavenima, uključujući i Rusiju. Nije tek povratkom Metodovih učenika iz Moravske počeo razmišljati koje pismo dati Slavenima. Mogli bismo reći da je u Bugarskoj nastavljana misija - bar što se tiče jezika i pisma - koja je bila u Moravskoj. Nije dakle uvjerljivo da je na početku Moravske misije nastala glagoljica, a u njezinu tijeku ili na kraju ćirilica, kao što to prikazuje Slika 4. S ćirilicom su učenici došli iz Moravske, s ćirilicom su nastavili u Bugarskoj, s ćirilicom će krenuti prema Rusiji.

Ćirilometodska teorija tu očito pravi nevjerojatan skok. Kako je moguće da učenici dolaze u Bugarsku s glagoljicom i da se u roku od osam godina stvori novo pismo (ćirilica) i da se ono već 893 . nametne kao službeno!? I zašto bi za istu svrhu Ćiril i Metod stvorili dva pisma? Ćirilometodska teorija želi sve riješiti jednom misijom, a njih je među Slavenima iz Bizanta bilo više. Najpoznatije i za nas najvažnije su dvije.

${ }^{18}$ Svoje mišljenje ne temeljim ni na jednoj dosad poznatoj teoriji koja nastanak glagoljice stavlja prije Misije u Moravsku iako mislim da ima i u tim teorijama elemenata koje treba proučiti u traženju sigurnijeg rješenja. Tako Marko Japundžić zastupa mišljenje da su za glagoljicu zaslužni franački misionari. Na temelju analize nekih staroslavenskih biblijskih tekstova kaže da oni nisu prevedeni ni iz grčkog originala ni iz Vulgate, već iz tzv. Vetus latine koja je bila u uporabi do Karla Velikog, što znači da je svakako taj prijevod stariji od Ćirila i Metoda (M. JAPUNDŽIĆ, 1995, 73-75).

${ }^{19}$ S. DAMJANOVIĆ, 2002, 50-52. 


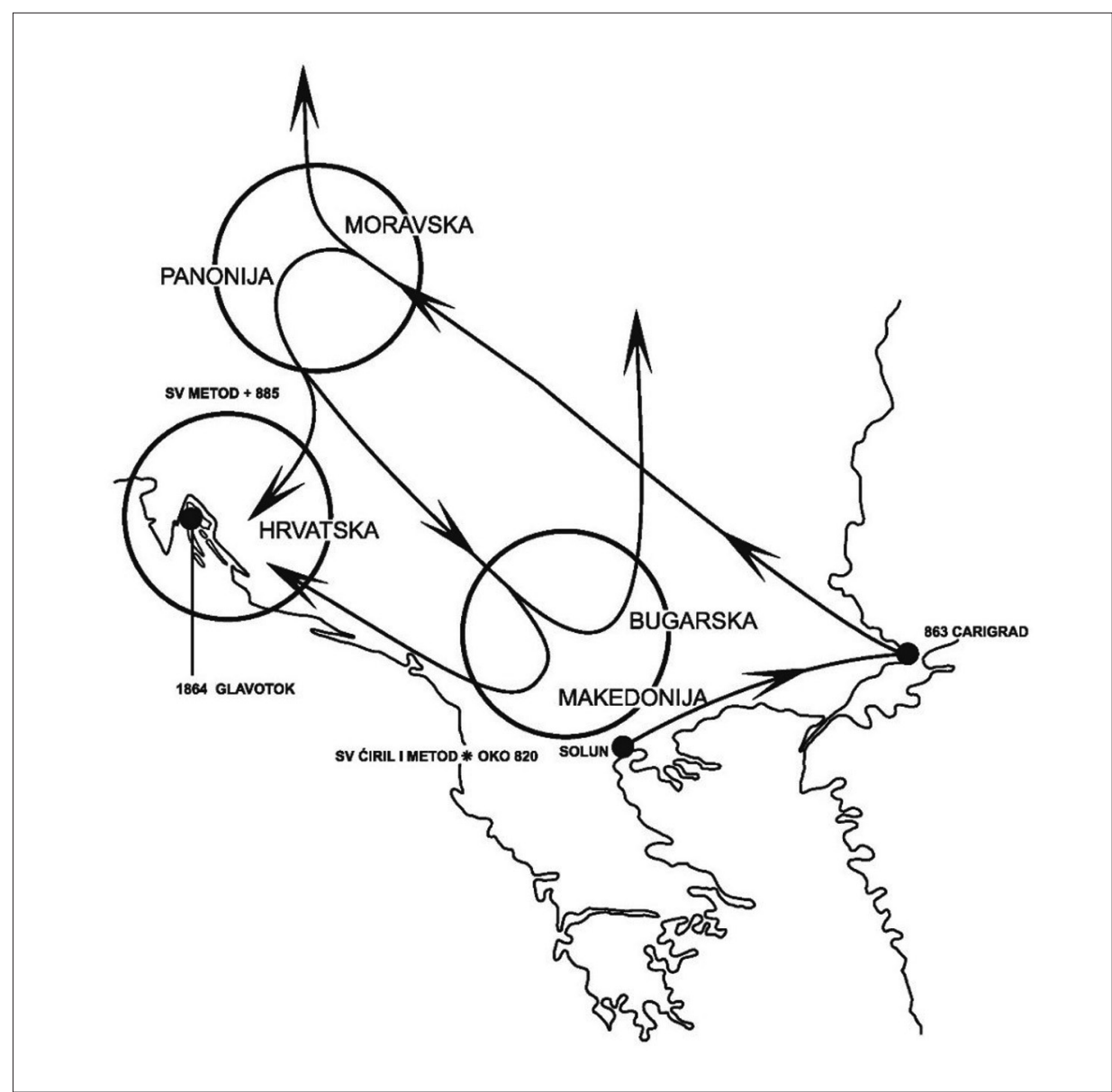

Sl. 4. Ćirilometodska teorija: jedna misija, dva pisma ${ }^{20}$ (doradio: Csaba Pinter)

Prva $^{21}$ je ona uz koju je, uz slavenski jezik, vezano i slavensko pismo glagoljica. Logično je pretpostaviti da je krenula iz Carigrada u krajeve naseljene

${ }^{20}$ Skicu je napravio Branko Fučić i objavio prvi put u časopisu Croatica Christiana Periodica $(1981,8,36)$. Prema toj skici, u Hrvatsku je glagoljica došla izravno iz Moravske i neizravno preko Makedonije, nakon progona Metodovih učenika iz Moravske. Tu je Fučić zapisao da je zadnji glagoljski zapis u Hrvatskoj u Glavotoku na otoku Krku, a datira iz 1864. godine. To za Fučića ima simboličko značenje jer je taj zapis nastao $1000(+1)$ godina nakon početka Moravske misije. Zato je na skici tako istaknut Glavotok 1864.

${ }^{21}$ Ovdje "prva" misija ne znači da imamo točan podatak kada je ona krenula i kako je bila organizirana. Iz vremena Velike seobe naroda poznata je metoda rada Crkve u susretu s nekrštenim 


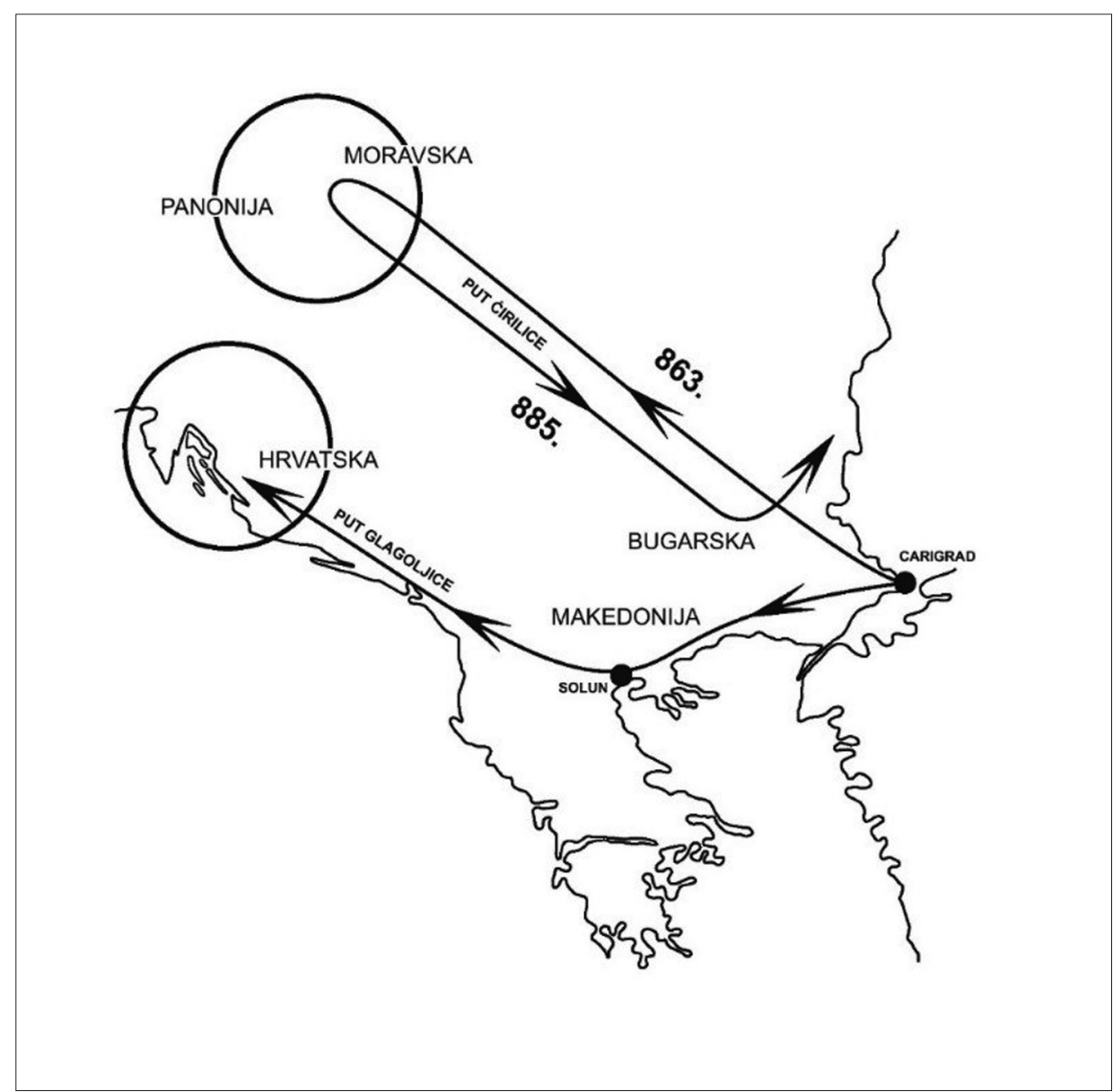

S1. 5. Dvije misije i dva pisma (autor: Csaba Pinter)

Slavenima koji su bili u najbližem kontaktu s kršćanstvom, pod bizantskom vlašću. Put je išao preko Makedonije u Dalmaciju i Istru. Sustavna kristijanizacija

narodima. I Crkva i kršćanska država osjećale su svojom obvezom da kristijaniziraju najprije one koje su došli na područje kršćanskog vladara, ali i to da se misionari šalju i u "susjedstvo". Iz povijesnih vrela znamo da su južna Makedonija te Bizantska Dalmacija i Istra prva područja organiziranog Carstva koje su Slaveni u znatnom broju naselili. Ta područja bila su dostupna jer su ono vrijeme morski putovi bili najlakši i najbrži. Na tim područjima nisu se raspale stare društvene strukture, što znači da je ondje postojala organizirana crkvena i državna vlast. Tu je, dakle, bio taj prvi susret i prva misija. Nemamo dovoljno podataka da bismo mogli odrediti točno vrijeme $i$ aktere toga misionarskog susreta (usp. M. BOGOVIĆ, 2019, 30-37). 
Slavena, dakle, počinje u krajevima oko Soluna, Dalmaciji i Istri, kako se vidi na Slici 5. Tu su Slaveni bili stalni susjedi pokrštenih naroda. S pokrštavanjem dolazi i glagoljica, pismo stvoreno za tu svrhu.

Ta misija vodila se tipično misionarskom logikom, prirodnim rastom i bez određenih termina. Zato su u pismu vjerski simboli kojima se izražava vječni Logos i mudrost križa Kristova. I abeceda/azbuka počinje s križem (slovo 1 je zapravo križ, s povučenim crtama na poprečnoj crti da se u tekstu razlikuje od križa), a postoje mišljenja da su sva slova izvedena iz Kristograma. ${ }^{22}$ Prisjetimo se da je car Konstantin gradio svoju prijestolnicu na Bosporu novu iz temelja da joj i korijeni budu kršćanski jer stari Rim ima poganske korijene. Ta ideja nosila je i bizantske misionare da u početke svoga rada ugrade kršćanski Logos i kršćanski duh. I u tome su uspjeli! Oni su za potrebe pokrštavanja stvorili glagoljicu, no to nije nigdje zapisano jer je bilo djelo vrsnih znalaca misijskog umijeća, ali ne i uglednika koji su bili povezani s patrijarsima i papama, carevima i kraljevima, što je slučaj s Ćirilom i Metodom.

Druga misija, ona Konstantina (Ćirila) i Metoda, nije bila, dakle, čisto misionarska nego i kulturno-politička. Kako je već rečeno, Ostrogorski naziva desetljeće od 860. do 870. velikim bizantskim decenijem. Poslije ruskog napada na Carigrad 860., počinje bizantska misionarska djelatnost u mladoj ruskoj državi; 863. idu misionari Ćiril i Metod u Moravsku misiju, već iduće godine i Bugarska službeno prihvaća kršćanstvo, a na saboru 869./70., nakon nekih kolebanja, konačno se uključuje u vjersku i kulturnu sferu Bizanta. Ostrogorski dodaje da u to vrijeme Bizant "prisiljava Bugarsku oružanom snagom da raskine savez sa Franačkom i da primi hrišćanstvo iz Carigrada". ${ }^{23} \mathrm{U}$ takvim okolnostima ne stavlja se naglasak na kršćansku simboliku. To je doba kada i misionarski rad postaje najefikasniji oblik bizantske kulturne i političke penetracije.

Poziv iz Moravske bio je iz naglašeno nacionalno-političkih motiva. Tako je i misija u Moravsku vođena jakim državničkim interesima. Uostalom, ta komunikacija bila je na razini državnih poglavara. U to vrijeme već su uspostavljene službene veze na grčkom pismu, koje je inače mnogo jednostavnije od glagoljice. Od cara Heraklija (610. - 641.) Bizant prihvaća grčko pismo kao službeno pismo Carstva. U toj široj viziji Moravske misije prevagnula je praktičnost i blizina grčke grafije, a ne bogatstvo vjerske simbolike glagoljskog pisma, pa je iz toga razloga nastala ćirilica s kojom su Konstantin i Metod

${ }^{22}$ M. ČUNČIĆ, 2003, 94-107.

${ }^{23}$ G. OSTROGOTSKI, 1970, 59-61. 
otišli u Moravsku. To je, dakle, povijesni kontekst u kojem se događa Misija u Moravsku. U taj kontekst ne može se uklopiti čisto misionarsko pismo glagoljica - s kojim su, možda čak dva stoljeća prije Ćirila i Metoda, krenuli prvi bizantski misionari među Slavene u Makedoniju i Bizantsku Dalmaciju. Ista je to misionarska škola, isti je i slavenski jezik, ali je zbog naravi ove misije uzeto drugo, jednostavnije pismo, koje se po svom tvorcu Konstantinu-Ćirilu zove ćirilica. To što je starija glagoljska misija bila usmjerena na prostore na kojima su se naselili Slaveni u Makedoniji i Bizantskoj Dalmaciji ne znači da djelovanje tih misionara, pojedinačno ili u skupinama, nije prelazilo te granice. Time bi se mogli tumačiti neki glagoljski grafiti izvan spomenutih područja. Poznato nam je da su tada odnosi između Hrvatske i Bugarske bili veoma intenzivni. ${ }^{24}$ Koliko je misija preko Makedonije u Hrvatsku starija, toliko je starija glagoljica od ćirilice. ${ }^{25}$

Nakon Raskola 1054. glagoljica prelazi u rimski obred, a bizantski obred napušta glagoljicu

U vrijeme bizantske vlasti u Dalmaciji Hrvati su primili bizantski obred i s njime i glagoljicu, ali je na tom istom području nesmetano i dalje živio i rimski obred jer je u ono vrijeme kršćanski suživot raznih obreda bio normalna stvar. Nisu ni Rim ni Carigrad u vrijeme svoje jurisdikcije zabranjivali jedan ili drugi obred. U Bizantskoj Dalmaciji mogla je glagoljica, dakle, biti u bizantskom i $\mathrm{u}$ rimskom obredu, ali je ona $\mathrm{u}$ vrijeme bizantske vlasti bila favorizirana, a $\mathrm{u}$ vrijeme zapadnjačke (rimske) vlasti bila tek tolerirana.

Kad je to područje potpalo pod hrvatskog kralja, došlo je i pod papinsku nadležnost. To su vremena upitnosti glagoljice za kralja Tomislava, a nakon Raskola 1054. ona je u 11. stoljeću, u vrijeme papinskih saveznika Krešimira IV. i Zvonimira, postala žestoko osporavana. Znamo da je još na Splitskoj sinodi 925. postavljeno pitanje drugog jezika u liturgiji (Methodii doctrina). ${ }^{26}$ Nije već tada bilo postavljano pitanje obreda. Kada

${ }^{24}$ I. DUJČEV, 1987, 27-34.

${ }^{25} \mathrm{O}$ vremenu kada je stvorena glagoljica može se za sada govoriti samo okvirno: onda kada su bizantski misionari počeli kristijanizirati Slavene naseljene na bizantskom (kršćanskom) području.

${ }^{26}$ U pismu pape Ivana X (925.) prigovara se dalmatinskim biskupima da podržavaju Metodovu doktrinu (Methodii doctrinam) što se često navodi kao prvi spomen glagoljice na našem prostoru. No tu se ne govori o pismu (slovima), nego o učenju Metodovoj doktrini da se u bogoslužju mogu koristiti narodni jezici (M. BOGOVIĆ, 2019, 42-45). 


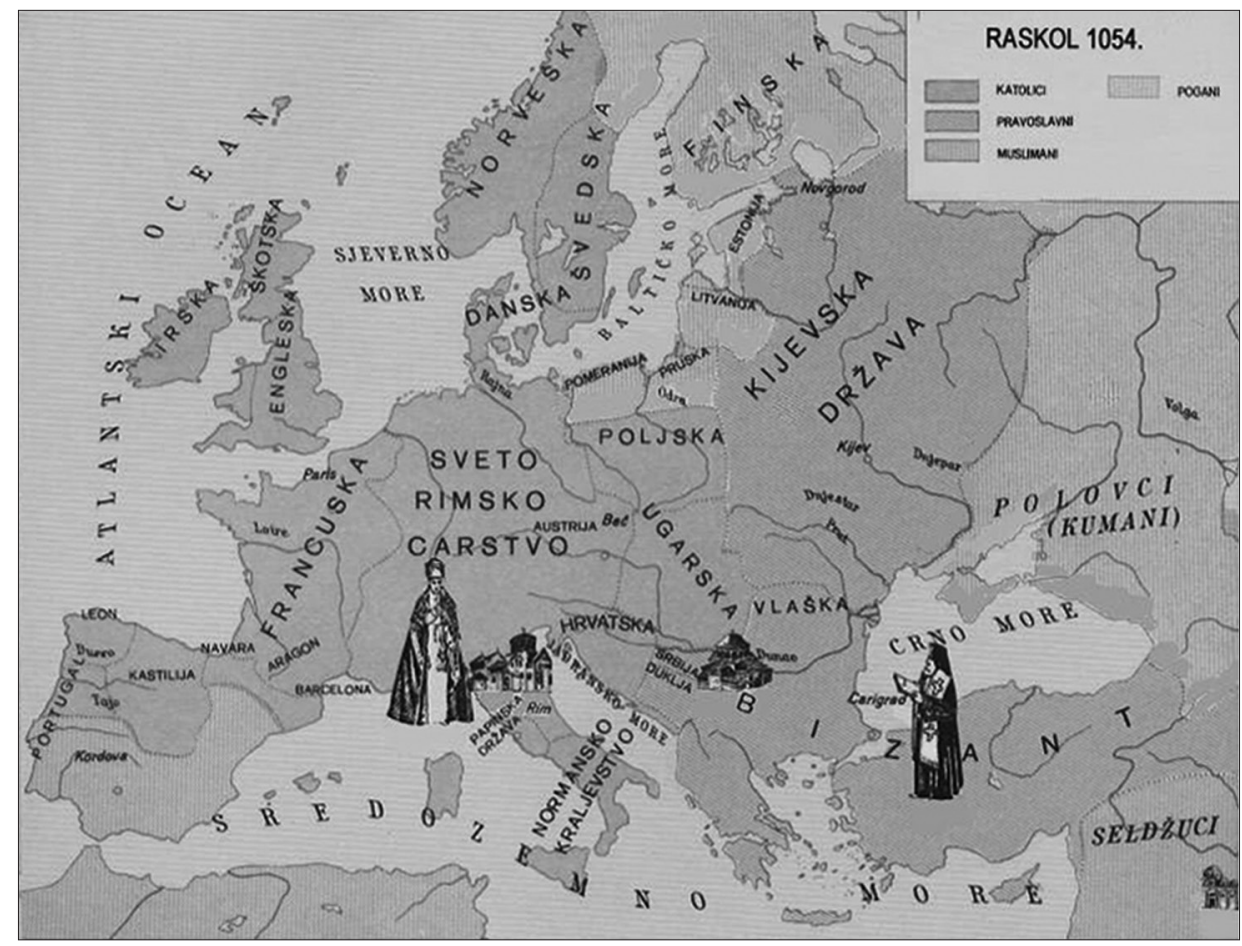

S1. 6. Raskol ili shizma kršćanstva na pravoslavlje i katolicizam (izvor: M. BOGOVIĆ, 2019, 47)

papa prigovara dalmatinskim biskupijama da se u njihovim biskupijama širi Methodii doctrina, tu nije posrijedi riječ o glagoljici kao Metodovom izumu, kako hoće zastupnici ćirilometodske teorije. Jedno je doktrina (nauk), a drugo su slova. Doktrina se u ovom slučaju sastoji u tome da se poruka Boga čovjeku i čovjeka Bogu prenosi razumljivim jezikom. Metod je u to vrijeme bio poznata osoba u kršćanstvu i tu je misao on javno zastupao, kao i brat mu Konstantin Ćiril u diskusiji u Veneciji. Taj nauk je, dakle, bio raširen i u dalmatinskim biskupijama. Nema tu govora o pismu, nego o nauku koji se tim pismom širi.

I u vrijeme upitnosti glagoljice za kralja Tomislava, otvorila su se njoj nova vrata za širenje. Naime, dolaskom Bizantske Dalmacije pod hrvatskog kralja uspostavljeno je novo crkveno ustrojstvo u hrvatskoj državi: ukinuta je hrvatska (Ninska) biskupija, a jurisdikcija biskupa Bizantske Dalmacije protegnuta u unutrašnjost. Time je ujedno otvoren 
veliki prostor za širenje glagoljice. S njome, dakako, dobiva šansu i bizantski obred, ali je još važnije da je ona mogla ulaziti u rimski obred koji je u hrvatskom kraljevstvu bio uveden u vrijeme pokrštavanja. Imamo, naime, starih glagoljskih tekstova u rimskom obredu, kao npr. Kijevski listići i Bečki listići. ${ }^{27}$ Tako se napad na glagoljicu pretvorio u otvaranje novih prostora za njezino širenje.

Kada je u 11. stoljeću došlo do raskola između Istočne (bizantske) i Zapadne (rimske) Crkve (1054.), u odnosima Istoka i Zapada, patrijarha i pape, nastalo je vrijeme kada se ističu i traže razlike da bi se opravdao i obrazložio razlaz. Upravo su tada hrvatski kraljevi, uz papinsku pomoć, ponovno protegnuli svoju vlast na Dalmaciju. Glagoljaši su izgubili oslonac koji im je do tada davao Bizant. U Katoličkoj Crkvi nije više bio dopušten bizantski obred. U opasnosti da ne dođe jednostavno do odlaska glagoljaša u shizmu, pronađeno je kompromisno rješenje: dopušteno je i dalje korištenje slavenskog jezika i glagoljskog pisma u bogoslužju, ali ne i bizantski obred. Što se tiče obreda, tu nije bilo kompromisa: svi su trebali prihvatiti rimski (latinski) obred. ${ }^{28} \mathrm{Uz}$ bizantski obred bili su vezani i neki drugi običaji, od kojih je najvažniji celibat svećenika. Pape su, kako je i napisano, posebno inzistirali na obvezi svećeničkog celibata pa im je i zbog toga smetao bizantski obred unutar kojega je celibat bio obavezan samo za monahe.

Toma Arhiđakon piše da je tada nastala smutnja i pobuna među klerom i narodom. ${ }^{29} \mathrm{~S}$ obzirom na obred, nije bilo popuštanja. Oni monasi koji nisu htjeli prihvatiti rimski obred, pokupili su svoje knjige i otišli u razne samostane na istok, jer su najveći pobornici bizantskog obreda bili upravo monasi (redovnici). ${ }^{30}$ Mogli su ostati samo oni koji su prihvatili rimski obred. Biskupijski svećenici nisu imali alternativu. I pored katkada bučnog

${ }^{27}$ K. KUHAR, 2018, 171-191.

${ }^{28}$ Bizantski ili grčki obred na Zapadu sačuvali su u Kalabriji i na Siciliji istočni monasi koje je rimska kurija nazivala bazilijanci. Monasi su se sklanjali onamo bježeći najprije pred Saracenima, a poslije pred Turcima. Bilo je više pokušaja da im se nametne rimski obred, ali se ipak bizantski obred sačuvao sve do dvadesetog stoljeća. Naselili su taj kraj i malobrojni vjernici laici istog obreda. Da se radilo o široj populaciji, vjerojatno bi bizantski obred bio dokinut već u 11. stoljeću.

${ }^{29}$ T. ARHIĐAKON, 2003, 72-77. Usp. L. MARGETIĆ, 2003, 179-197.

${ }^{30} \mathrm{U}$ svojoj citiranoj knjizi o glagoljici spomenuo sam neke knjige koje su sačuvane na Atosu i na Sinaju (M. BOGOVIĆ, 2019, 52-53). To je moguće, ali pozitivnog dokaza nema. U analizi kalendara Assemanijeva evanđelistara jasno se vidi da on nije došao iz Dalmacije. 
negodovanja i protivljenja, što se vidi i u pripovijedanju Tome Arhiđakona o Vuku, Zdedi i glagoljašu krčkom biskupu ${ }^{31}$, morali su se pomiriti s tim kompromisnim rješenjem. Kako rekosmo, bilo je i do tada svećenika glagoljaša rimskog obreda, ali sada su to trebali prihvatiti svi. Sva je prilika da je na području hrvatske kraljevine, kada se jurisdikcija obalnih i otočnih biskupija protegnula na cijelo kraljevstvo, glagoljica u mnogo slučajeva već ušla i u rimski obred, što bi mogao biti jedan od važnih razloga da ona nije ukinuta.

Hrvatski su kraljevi, izgleda, nakon Raskola zagovarali glagoljaše jer su time lakše zadržali svoje pravo na dotad bizantsko područje. Dobar je primjer kralja Zvonimira koji dolazi na Krk i potpomaže osnivanje benediktinskog samostana u Jurandvoru, o čemu nam govori Bašćanska ploča. Prema darovnici slavnoga Dragoslava, u vrijeme Bašćanske ploče, glagoljica je bila prošireno pismo u puku. ${ }^{32}$

U vrijeme Raskola, dakle, nestaje u Hrvatskoj bizantski i svuda se uvodi rimski obred (bizantskih tragova će biti i poslije.) Kada su svi glagoljaši nakon Raskola prihvatili rimski obred, olakšano je širenje glagoljice u cijelom hrvatskom prostoru gdje je taj obred već bio uveden. Svakako je smjer njezina širenja išao od obale prema unutrašnjosti, a ne obratno. ${ }^{33}$

Obje krize, i onu za vrijeme kralja Tomislava i onu nakon Raskola, glagoljica je u Hrvatskoj uspješno prevladala. No nije izdržala i na Istoku (Makedonija) jer joj se ondje gube tragovi. Možemo reći da Raskolom glagoljica napušta u Hrvatskoj bizantski obred, a u Makedoniji bizantski obred napušta glagoljicu. Mogu se samo nagađati razlozi zbog kojih bizantski obred napušta glagoljicu. U napetostima i prekidu odnosa između patrijarha u Carigradu i pape u Rimu, možemo pretpostaviti, u Carigradu nisu lako primili prijelaz hrvatskih glagoljaša u rimski obred pa je i patrijarh nametnuo ćirilicu gdje je bila glagoljica. No, to je samo slutnja za koju za sada nema dokaza. Nestanak glagoljice na Istoku može se shvatiti i tako da je i Carigrad naredio slično kao što je Preslavska sinoda 893. odredila za Bugarsku: da se među Slavene ide samo s jednim pismom - ćirilicom.

${ }^{31}$ T. ARHIĐAKON, 2003, 72-77.

${ }^{32}$ J. KIRINČIĆ - F. VELČIĆ, 2000.

${ }^{33}$ Nada Klaić je najtemeljitije i najopširnije izložila da se glagoljica u Hrvatskoj širila od mora prema kopnu, a ne obrnuto. (N. KLAIĆ, 1965, 225-281) 


\section{I dalje ima teškoća i dilema}

Potrebno je odgovoriti i na pitanje zašto je za Moravsku misiju trebalo stvarati drugo pismo kad je za Slavene puno prije stvorena glagoljica. Treba priznati da za to nemamo ni povijesnog ni filološkog obrazloženja. U srednjem vijeku bili su jaki vjerski ili teološki razlozi. Pozivom moravskog kneza pred Bizantskim Carstvom nalazio se veliki izazov i iskorak. Trebalo je to predstaviti kao izričitu Božju volju. Još krajem 11. stoljeća znamo da je papa Urban II. pokrenuo cijeli Zapad na križarsku vojnu riječima: Bog to hoće! Kada to Bog hoće, onda ne trebaju predradnje, niti ih se smije spominjati. To onda mora biti u cijelosti izvorno Njegovo djelo. Zato sâm Bog i u ovom slučaju objavljuje Ćirilu (Konstantinu) slova. ${ }^{34}$ Kada bi se navodilo ono što postoji od prije (glagoljica), oduzela bi se ćirilici snaga i ugled izravnog i originalnog Božjeg zahvata. To je u skladu s načinom mišljenja tadašnjeg svijeta.

Nećemo, dakako, reći da su prije Ćirila i Metoda postojali gotovi gramatika i rječnik slavenskog jezika, ali je još naivnije misliti da su u drugoj polovini 9. stoljeća ondje bile od slavenskog jezika samo "črte i reze", a Slaveni su već tri stoljeća u svojoj novoj postojbini. Tako su nastala dva pisma za isti jezik. Mislim da je na cijelom prostoru djelovanja bizantske misionarske škole bila ista jezična politika. Iz te škole izišli su Ćiril i Metod kao i njihovi (nepoznati) prethodnici. Dakako, ta dvojica dali su jak pečat slavenskim misijama i pitanje je koliko bi se posebni jezik i pismo u Bizantskoj Dalmaciji i južnoj Makedoniji sačuvali da se njih dvojica nisu uključila u misijsku djelatnost. Oni su komunicirali s papama, carevima, kraljevima i knezovima, što je rijetko kojem misionaru uspijevalo. Glagoljaši su također štovali sv. Ćirila, kako to pokazuje i (glagoljsko) Assemanijevo evanđelje u kojem se 14. veljače spominje spomen "s(ve)tago našega otca Kyrilla Filosofa". ${ }^{35}$ Tome bih dodao kako je Marica Čunčić u novije vrijeme pisala da je najstarija trokutasta glagoljica (uz okruglu i uglatu) i da je ona prisutna kod nas na Krčkom natpisu i Bašćanskoj ploči. ${ }^{36}$

${ }^{34}$ Žitja Konstantina ćirila i Metodija i druga vrela, 1985, 70-71.

${ }^{35}$ I. ČRNČIĆ, 1878, 100.

${ }^{36}$ M. ČUNČIĆ, 2003, 108-111. 


\section{Zaključno}

O početcima glagoljice te o njezinom širenju i razvoju postoji dosta teorija, a najproširenija i najprihvaćenija je ona ćirilometodska. Po toj teoriji glagoljica i ćirilica u svojim početcima vezane su uz Moravsku misiju čiji su glavni protagonisti bili Konstantin-Ćiril i njegov brat Metod. $\mathrm{Na}$ molbu moravskog kneza Rastislava, car Mihajlo III. šalje dvojicu braće 863. u Moravsku, a prethodno su oni stvorili pismo glagoljicu i preveli najpotrebnije knjige na slavenski jezik. Nakon uspješnih koraka ta misija je smrću Metodovom 885. propala, a učenici su se razbježali i tako raširili glagoljicu u Hrvatsku i Makedoniju. Prema toj teoriji za pokrštene Bugare dotad nepoznati autor stvorio je ćirilicu, koja će postati baština pravoslavnih Slavena. Jednostavno je nastanak ćirilice pao u sjenu kad je Ćirilu pripisana glagoljica.

U ovom radu iznosim drukčije mišljenje: za Moravsku misiju stvorena je ćirilica, a glagoljica je stvorena prije, na početku djelovanja bizantskih misionara među Slavenima u Hrvatskoj (Bizantskoj Dalmaciji) i krajevima oko Soluna (Makedonija). Oba pisma djelo su iste bizantske misionarske škole, ali je glagoljica nastala iz čisto misijskih potreba među poganskim Slavenima koji su se smjestili na prostore gdje su kršćanstvo i njegove strukture preživjeli stradanja u velikoj Seobi naroda; ćirilica je pak nastala u vrijeme jakog državno-političke ekspanzije Bizanta među Slavenima. Nije dosad dovoljno naglašeno da je za život glagoljice važnost imao vjerski raskol između Istoka i Zapada (1054.): tada će Rim tražiti od glagoljaša u Hrvatskoj da prihvate rimski ili latinski obred, a na području bizantske vlasti na Istoku glagoljica je izgubila svaku podršku i svuda je uzmicala pred ćirilicom te je u 12. stoljeću sasvim nestala iz bizantskog obreda. Raskol je, dakle, bitno utjecao na daljnju sudbinu glagoljice $\mathrm{i}$ ćirilice. Budući da su oba pisma nastala za isti (slavenski) jezik, a nekoliko stoljeća koristila su se oba pisma u istom (bizantskom) obredu, pod jezičnim vidom tvorci ćiriličkih i glagoljičkih tekstova znali su se koristiti jezičnim dosezima obiju strana i prepisivati tekstove iz jednog u drugo pismo, o čemu imamo brojna svjedočanstva.

Povijesni kontekst nastanka glagoljice i ćirilice nije tako proučen i jasan da bi se pitanje nastanka glagoljice i ćirilice moglo skinuti s dnevnog reda. Povjesničari trebaju pratiti dosege filološke znanosti, ali i filolozi trebaju smjestiti svoja istraživanja u povijesni kontekst. 


\section{Literatura}

Toma ARHIĐAKON, Povijest salonitanskih i splitskih prvosvećenika, Splitski književni krug, Split, 2003.

Atlas zur Kirchengeschichte, Herder, Freiburg - Basel - Rom - Wien, 1987.

Anđelko BADURINA, Bizantski plovni putovi po vanjskom rubu sjevernojadranskih otoka, Radovi Instituta za povijest umjetnosti u Zagrebu, god. 16., 1992.

Mile BOGOVIĆ, Glagoljica - bitna odrednica hrvatskog identiteta, ALFA, Zagreb, 2019.

Neven BUDAK - Tomislav RAUKAR (ur.), Povijest Hrvata srednjega vijeka, Školska knjiga, Zagreb, 2006.

Ivan ČRNČIĆ, Assemanovo izborno evanđelje, Rim, 1878.

Marica ČUNČIĆ, Oči od slnca, misal od oblaka - izvori hrvatske pisane riječi, Školska knjiga, Zagreb, 2003.

Stjepan DAMJANOVIĆ, Slovo iskona, Matica hrvatska, Zagreb, 2002.

Geert van DARTEL, Ćirilometodska ideja i svetosavlje, Kršćanska sadašnjost, Zagreb, 1984.

Ivan DUJČEV, Croazia intermediario fra la Bulgaria e Roma alla fine del secolo nono ed all' inizio del secolo decimo, Slovo, 37, 1987, 27-34.

Branko FUČIĆ, Glagoljski natpisi, Djela Jugoslavenske akademije znanosti i umjetnosti, knjiga 57, Zagreb, 1982.

Marko JAPUNDŽIĆ, Tragom hrvatskog glagolizma, Novaja i vethaja, knjiga 5, Zagreb, 1995.

Josip KIRINČIĆ - Franjo VELČIĆ, Darovnica slavnoga Dragoslava, Rijeka, Općina Dobrinj, otok Krk, 2000.

Nada KLAIĆ, Historijska podloga hrvatskog glagoljaštva u X. i XI. stoljeću, Slovo, 15$16,1965,225-281$.

Kristijan KUHAR, Utjecaj tekstova latinskih rimskih sakramentara na crkvenoslavensku rimsku liturgiju (9. - 14. stoljeće), Slovo, 68, 2018, 171-197.

Lujo MARGETIĆ, Uzmak Bizanta na otoku Krku sredinom 11. stoljeća, Hrvatska crkva u srednjem vijeku, Rijeka 2003, 179-197.

Grigorije OSTROGORSKI, Vizantija i Sloveni, Prosveta, Beograd, 1970.

Leonard TANDARIĆ, Sveti Ćiril i Metodije-Novi pristup evangelizaciji, Bogoslovska smotra, 55, 1986, 369-375.

Žitja Konstantina Ćirila i Metodija i druga vrela (preveo i protumačio Josip Bratulić), Kršćanska sadašnjost, Zagreb, 1985. 


\section{THE GLAGOLITIC AND CYRILLIC SCRIPTS ARE THE FRUITS OF TWO SEPARATE BYZANTINE MISSIONS AMONGST THE SLAVS}

\section{Summary}

It is usually said and written that the Glagolitic and Cyrillic scripts were, in their origins, connected with the Moravian mission whose main protagonists were Constantine-Cyril and his brother Methodius. The author of this text considers that each of these two alphabets is related to one of two different missions in different areas and at different times. The Glagolitic script originated in the beginnings of the Christianisation of the Slavs in Croatia (Byzantine Dalmatia) and the areas around Solun-Thessaloniki (Macedonia), whilst the Cyrillic script is associated with the activities of the Holy Brothers Cyril and Methodius during the Moravian Mission (863-885). Both alphabets are the work of the same Byzantine missionary school, however, the Glagolitic script originated earlier from purely missionary needs, whilst the Cyrillic script originated during the strong state-political expansion of Byzantium amongst the Slavs during the "Great Byzantine Decade" (870-880).

At the time of the Great Schism (1054), Rome would ask Glagolitic scribes or priests in the area of its jurisdiction in Croatia to accept the Roman or Latin rite. In Macedonia, the Glagolitic script lost all support and retreated everywhere before the Cyrillic script, and in the $12^{\text {th }}$ century, it completely disappeared from the Byzantine rite. Being that both scripts were written for the same (Slavic) language, from the linguistic aspect, the connections between them continued, which can be noticed in Glagolitic and Cyrillic texts.

Keywords: Glagolitic, Cyrillic, rites, missionary schools, 1054 Schism, Byzantine Dalmatia, Macedonia 